\title{
ARTICLES
}

\section{AL-GHAZĀLT̄ AND THE FOUNDATIONS OF AN ISLAMIC HUMANISM}

\author{
Anthony H. Johns* \\ Free Muslims from legal restrictions as far as you can \\ / Idfa 'al-hudūd 'an al-muslimīna mā wajadtum...'
}

\begin{abstract}
While the famed Muslim jurist-theologian Abū Ḥāmid al-Ghāzālī is widely acclaimed for his reconciliation of Islamic mysticism (tașawwuf) with the Law, he also exemplified the centrality of a Humanist tradition in Islam. His work Kitāb ādāb al-samā' wa l-wajd [Protocols for Spiritual-Audition and Ecstasy] presents a view of humanity existing at diverse spiritual levels and portrays the wonder of divine love, the humanity of the Prophet, and the legitimacy of human joys and pleasures - in particular poetry, music and dance. Ghāzālī established the basis for a God-centred Humanism that values secular activities for their potential to advance spiritual life, while according full respect to the Law. His pioneering thought distils important principles that are of great relevance for Muslim thinkers and planners today, including the importance of freeing Muslims from legal constraints as far as possible within the sanctity and authority of the Law, and the need to continually refresh the Islamic legacy and advance spiritual life through finding value in worldly activity. His investigation of 'spiritual audition' opens the door onto a world of spirituality and dialectic arising from a loving awareness of mundane human experience.
\end{abstract}

\section{Introduction}

The contribution of the leading Shāfi ite jurist and Ash 'arite theologian Abū Hâmid al-Ghazālī to Islamic thought and spirituality was immense. His ultimate achievement is usually described as the reconciliation of Mysticism with the Law, thereby securing for Sufi tradition (tașawwuf) a legitimate place in the Islamic disciplines. This essay is based on our draft of an English translation of his work on the practice of spiritual audition, Kitāb $\bar{a} d \bar{a} b$ al-sama ' 'wa l-wajd [The Protocols of spiritual-audition and ecstasy $]^{2}$, and attempts to show another dimension of his work as an advocate for and exponent of the rich tradition of Islamic humanism. 
Ghazāli is often spoken of as having reconciled the Law and mystical experience. This statement is based on a misdefined premise. Although his Adab $a l-s a m \bar{a}^{\prime}$ is framed as a juridical issue focused on the question over whether sam $\bar{a}^{3}$ and $w a j d^{4}$ are permissible, he is not indulging in a mere intellectual exercise as if to say: here is the Law, here is mysticism, let us reconcile them. Rather his approach is: here is our experience of God, the Prophet He sent to us, and the Book the Prophet has brought; here is the world he has provided for us, and the joys we may find in it as we serve Him. His approach is one that lives Islam as comprising all these elements.

Kitāb $\bar{a} \bar{a} \bar{a}$ al-sam $\bar{a}^{\prime}$ wa $l$-wajd reveals a genuine Islamic humanism, an experience of God that inspires a love of humanity and becoming aware of the presence of God through our human experience. Ghazālī rejects a formalistic commitment to religion and with it the puritanical stream in Islam. Notwithstanding his respect and reverence for the great legal theorist Muhammad b. Idrīs al-Shāfi 'î (d. 204/820), he does not share his dislike of chess and backgammon as inappropriate for scholars of religion. He finds within the Law a place for poetry, music (both instrumental and vocal), as well as for dance and movements - whether as amusement for the common people, or as aids to progress in the spiritual life. Ghazālī views religious life in Islam as a continuum - from those called to experience ecstasy (wajd), to the everyday follower of religious requirements among the common people. He reveres the Law, but it is in the spirit of his treatment of the Prophetic utterance counselling leniency in suspending legal punishments (although he does not quote it): Free Muslims from legal restrictions as far as you can, and if you find a way of release then clear its path. ${ }^{5}$ It is in such details that he reveals the foundations of an authentic Islamic humanism.

This humanism is God-centred throughout. While Islam is not a sacramental religion in the Christian sense of the words, everything in creation is a sign of God. Ghazālī states, "Every good and beautiful thing in the world perceived by the mind, by sight, hearing and the other senses, from its beginning to its end, from the summit of the Pleiades to what lies beneath the soil, is but a grain out of the treasure chests of His power, and a ray from the light of His presence. Glorious beyond compare is $\mathrm{He}$ who is veiled from being visible by the very intensity of His manifestation and is hidden from sight by the radiance of His light." One thinks of Hopkins' sonnet,

The world is charged with the grandeur of God. It will flame out, like shining from shook foil. 
Ghazālī has this awareness of the wonder of creation. He delights in listening to birds singing and the beauty of nature, for every such experience is a sign of God. He understands human problems and weaknesses on the spiritual path. $\mathrm{He}$ is aware that language is arbitrary, that a single phrase can communicate multiple and seemingly contradictory meanings, and that poetry may sometimes be a remedy for the staleness that over familiarity with the Qur'ān might bring.

His work The Protocols of spiritual-audition and ecstasy also reveals much of al-Ghazālī's personal values as a human being. For him, the Law is not an inert set of rules but something dynamic and alive responsive to human life and experience. Even though the Law is not reducible to a fluid structure of situational ethics, it possesses a social and circumstantial dimension. He sees this exemplified in the warmth and human kindness of the Prophet, his appreciation of poetry, and his solicitude for women and children-inviting them to watch the Abyssinian war games, and over-riding Abū Bakr's objection to ' $\bar{A}$ 'ishah and two girls playing with tambourines.

Far from simply arguing for their permissibility, al-Ghazālī displays an enthusiastic love and appreciation for music, poetry and dance, and celebrates their roles in social life-even while he cautions against possible occasions of sin. He asserts that amusement (lahw), play (la $i b)$ and inconsequential talk $($ laghw) have their place in human life and are not to be condemned out of hand. The word dour is not in his vocabulary, and he exhibits a special love for music. Ghazālī marvels at how song may still a child crying in its cradle, and how on hearing music the camel, a dumb animal, finds heavy burdens light and long distances short. The task of the camel is to carry burdens, and that of humankind to seek God. Music stimulates both to the point that a camel may drop dead with exhaustion, and a man be so overcome with ecstasy that he departs this life.

Indeed, al-Ghazâlī loves voice, melody, and rhythm, and is amazed at the mysterious states the soul can experience such as fear, sorrow or joy-occurring in the sessions of $s a m \bar{a}^{\prime}$ when poetry is sung. However, music without words may take one even higher. "The sound of stringed instruments and other kinds of musical tonalities without any intelligible content, can have an extraordinary effect on the soul. It is not possible to express the wonder of them. They produce a sensation that may be described as yearning (shawq), but it is a yearning that the one who experiences it does not know what he yearns for, and it is extraordinary that one whose heart is stirred by listening to the sound of string instruments, flutes and the like, does not know what he yearns for. He discovers in himself a state of aching longing, a longing for something, yet he does not know what it is, (and this may happen) even to common people and those whose hearts have never been overwhelmed by love either of God or man." " This yearning, he implies, is for God Himself. 


\section{The Text}

Translation is often a thankless task which rarely succeeds in communicating the full range of a great writer's thought, and wittingly or unwittingly may misrepresent aspects of his argument. Even so, one of the closest ways of engaging with any text in a foreign language is to attempt to translate it into one's own. In the attempt to translate should occur a kind of conversation with the author: a questioning of him: what he meant by this, why did he say that? Did he have a single or diverse audience in mind when he wrote? Was there any overriding issue that motivated him, over and above the specific issue to which he addressed himself? In the case of al-Ghazālī, translation offers the opportunity to learn more of him, of his contribution to his shaping of the understanding of what it means to be a Muslim, and of development within the Muslim tradition itself.

Formally, his work is an investigation into a disputed issue: the legal status of listening to music (instrumental and vocal), in particular the use of music to arouse religious emotion and so induce ecstasy. ${ }^{7}$ The title The Protocols of sama $\bar{a}$-sessions and ecstasy is brief and formal. The result of his investigation is likewise formal, expressed with the succinctness of a fatwa : that such sessions in themselves are mubāh permissible; but participation in them may be harām unlawful, makrūh undesirable, haläl permissible, or mustahabb commendable according to the age, disposition and circumstances of the participants. ${ }^{8}$ Ghazāli further makes a distinction between the activity of music making itself and of listening to music, and the inner disposition of the participants, their mentality, motivation, level of spiritual attainment and related factors.

The work opens with an impassioned invocation:

Praise be to God who sets ablaze the hearts of His saints with the fire of His love, and enraptures their aspirations and spirits with yearning to meet $\mathrm{Him}$ and behold Him; Who brings their eyes and inner perceptions to a halt in reflection on the Beauty of His presence until they become intoxicated by the fragrance of the breath (rūhl) of union with Him, and by reflecting on the splendour of His Majesty (aljalān) their hearts are bewildered and filled with perplexity. Then in both existences [visible and invisible] they see none other than $\mathrm{He}$, and in both domains [this world and the hereafter], speak of none other than $\mathrm{He}^{9}$

This sets the tone for what follows, making clear that when individuals draw close to God, it is God Himself who first implanted in them this longing to draw close to Him. It lays emphasis on $\operatorname{sam} \bar{a}^{\prime}$, the key word in the title of the book, when it states that this setting ablaze is through the ear by the sense of hearing or spiritual audition: "There is no way to arouse what is hidden within human hearts other than by the spark provided by the sense of hearing, there being no access to the heart other than by the gateway of the ear." 
The work is divided into two chapters, the first devoted to $\operatorname{sam} \bar{a}^{\prime}$, the second to wajd. Chapter one, the primary source for our essay, consists of three parts: the first defining sam $\bar{a}$, and presenting some of the views for and against it by earlier authorities; the second proving that in itself, it is muba h permissible, and the third is a response to several arguments made against it. This framework might appear aridly academic, yet despite his claim to be applying a legal algorithm to this issue al-Ghazāli infuses into his argumentation alongside respect for the Law a love and enthusiasm for all that is human. Moreover, his demonstration that the grounds for the disapprobation of music, and leisure more generally, are circumstantial and not intrinsic to it, leads him in directions which may at first sight seem unexpected.

In part one he juxtaposes views of the classical jurists indicating they regard $\operatorname{sam}_{\bar{a}}{ }^{\prime}$ as Unlawful as reported by Abū 1-Ṭayyib al-Tabarī, against those of its practitioners. Shāfi $\overline{1}$ had declared singing to be an undesirable amusement (lahw), and the leading Iraqi jurist Abū Ḥanīfah (d. $768 \mathrm{CE}$ ) regarded listening to it to be sinful. Indeed, al-Ghazālī cites al-Shāfi '̄i: "I do not like playing chess, and I regard every game by which people amuse themselves as Undesirable, because games are not appropriate for those concerned with religious learning, or who have a sense of propriety (murü 'ah)." ${ }^{10}$ Against this, he reports the story told of the learned man Ṭāhir b. Bilāl al-Ḥamdānī al-Warrāq who stated,

I used to devote myself to prayer in the mosque in Jiddah beside the sea. One day in one of its alcoves I saw a group [of Sufis] reciting and listening to poetry. In my heart I condemned it, saying to myself, "Are they reciting poetry in a house of God?!" Then that night, I saw the Prophet sitting in that very place and Abū Bakr al-Șiddīq was beside him - and Abū Bakr was reciting a piece of poetry and the Prophet was listening to him, holding his hand against his breast, as though entranced by it. I said to myself, "It is not right that I condemn them for listening to poetry, when here is the Messenger of God listening to it while Abū Bakr recites it?" The Messenger of God then turned and said to me, "This is truth by truth", or "This is truth from truth" - I am not sure of his exact words.

For good measure he includes an intermediate position, that of the prominent Meccan authority 'Abd al-Malik Ibn Jurayj (d. 766) who permitted the holding of sessions of samā'. He was asked, "On Judgement Day, will this be reckoned among your good or your evil deeds?" Ibn Jurayj replied, "Neither one nor the other, because it is like indulging in empty talk (laghw) of which God says, "God will not take you to task for empty talk when you swear oaths" ( $Q$ al-Baqarah 2:225, \& al-Má'idah 5:91). Ghazālī thereby sets out the three possible positions toward practicing spiritual audition, and argues that since this disagreement exists, rather than adopt one view or another on the basis of personal preference 
let alone taqlid, "one should seek truth by the way proper to it, that is, by investigating the legal principles by which prohibition and permissibility are determined." ${ }^{\prime 11} \mathrm{He}$ chooses to proceed not by the adequate and readily available negative path that since there is no scriptural authority, or any argument based on such authority, to prove that participation in $s a m \bar{a}^{\prime}$ sessions is Unlawful, it is thereby Permissible; rather he demonstrates that these authorities themselves prove that it is Permissible. His choice of this procedure, although strictly speaking unnecessary, is not arbitrary since it allows him to show how wide is the variety of styles of performance subsumed under the term $s a m \bar{a}$, and to illustrate the aesthetic and spiritual riches it subsumes. More importantly, it affords him the opportunity to give an exposition of the circumstances affecting the legal status of an individual's performance of an act in itself Permissible, and to give an account of the broader principles and considerations lying behind the provisions of the Law. In this manner al-Ghazāli indicates lines of development already established which enable a continually adaptive theology of the Law.

\section{Four Components}

It is on the basis of such considerations that he opens his discussion with a general statement: The act of singing involves listening to a pleasant sound which has rhythm, conveys meaning and stirs the heart. Of these terms 'pleasant sound' is the broadest in meaning. It can be sub-divided into those that have rhythm and those that do not; those that are rhythmic are subdividable into those that have meaning such as poetry, and those that lack meaning such as sounds issuing from inanimate things or those produced by animals. In the light of these sub-divisions, he discusses the four components of the term 'singing voice' in some detail.

1) The first is 'pleasant sound'. That listening to a 'pleasant sound' is not Unlawful can be proved by inferential reasoning (in al-Ghazālī's terminology qiy $\bar{a} s$ ), for reason indicates that each of the five senses has a pleasure specific to it. This is also proven by revelation in the Qur'ān and Hadīth. Among these is the utterance: 'God never sends a prophet without a beautiful voice.' ${ }^{12}$ The Messenger said, 'God gives ear more intently to a man reciting the Qur'ān with a beautiful voice, than does the owner of a singing girl to her singing. ${ }^{13}$ The Qur'ān (al-Fätirir 35:1) utters, '...He adds to His creation whatever He wills', said to refer to beautiful sounds; and by implication the verse (Luqmān 31:19) 'The ugliest of sounds is the braying of the donkey' suggests the opposite! He takes this argument a stage further when he counters the claim that such listening is Permissible only in the case of listening to the Qur'ān, by a reductio ad absurdum: it would follow from this that listening to the singing of nightingales be declared Unlawful because it is not from the Qur'ān. For if listening to a spontaneously produced sound without meaning is Permitted, why should it not be Permissible 
to listen to a sound from which can be learned wisdom and with it virtuous ideals? Something revealing of his humanity may be glimpsed in al-Ghazālî̀s description of the pleasures to be derived from the mind and the senses. Humankind possesses reason ( 'aql) and five senses, and each sense has a specific perception $(i d r \bar{a} k)$ and finds pleasure in what it perceives. Thus, the pleasure of sight is in things beautiful to behold such as greenery, flowing water, an attractive face, and in sum, every beautiful form. These are the opposite of gross, ugly shapes that everyone finds disagreeable. The pleasure of the sense of smell is in fragrant odours, the opposite of unpleasant odours. The pleasure of the sense of taste is in delicious foods such as rich meats, sweet pastries, and foodstuffs that are piquant - the opposite of what is bitter and nauseating. The pleasure of the sense of touch is in the feel of what is smooth and delicate - the opposite of rough and coarse. While the pleasure of the intelligence is in knowledge and understanding - the opposite of ignorance and stupidity. In the same way, sounds perceived by the sense of hearing may be divided into those which give pleasure, such as the song of the nightingale and the sound of the flute, and those that are disagreeable, such as the braying of the donkey.

2) The second component is 'sounds with rhythm'. These may be produced from inanimate material or the throats of living creatures whether animal - nightingales, turtledoves or pigeons - or human. By 'sound produced from inanimate materials' he means musical instruments. His justification for making such instruments is that the craftsmen who make them do so in imitation of nature, and everything they fashion has within it an image (mitha $\bar{l}$ ) replicating the innate character God appropriates for a thing when He creates it. Thus the playing of musical instruments - apart from those specifically prohibited by the Law - is Permissible. ${ }^{14}$

Attention needs to be given to his explanation as to why the playing of certain instruments is prohibited. It is not because of their sound. Rather the reason is analogous with why certain types of jars which at one time used to hold wine and were emblematic of drinking sessions are Unlawful: they bring wine to mind, and arouse a longing to drink wine. The same applies to certain types of flutes and drums: the beating of the $k \bar{u} b a h$ - a long drum narrow in the centre with broad extremities - is deemed Unlawful since it is often beaten by transvestite male performers (mukhannath). Were it not for this, drums would be treated just like those drums beaten by pilgrims on the Hajj, or by warriors marching to war. They are deemed Unlawful because of what they might lead to, just as being alone with a woman outside the prescribed degrees of kinship is Unlawful because it could lead to sexual intercourse, or looking at her thigh because of its proximity to her genitals. In the same manner even a small sip of wine is declared Unlawful even if it does not cause intoxication, because it is a temptation to drunkenness. 
However he makes the point that in particular circumstances geography and social custom may be relevant to a legal judgement: the wearing of the $q a b \bar{a}$, with the hair of the head shaved and tied into tufts is forbidden in countries where the $q a b \bar{a}^{\prime}$ is normally worn by wicked persons. Yet this is not forbidden in Transoxania (central Asia) due to this being the customary hairstyle of virtuous people among them. From this it becomes clear that the reason they are declared as Unlawful is not due to the pleasure they give. Rather, it follows from the analogy that everything that gives pleasure is Lawful except those things which if they were deemed Lawful would actually involve harm. The Almighty says (al-A 'räf 7:32): Say, 'Who dares declare Unlawful the beauty God has made, which he has produced for his servants, and the pleasurable things by which he sustains them?'

3) The third component is meaning itself. Sound combined with rhythm and meaning serves as a definition for poetry. For al-Ghazālī reasons that since sound and rhythm are Lawful, the addition of meaning as well must be Lawful, provided what is said is not morally dangerous. Thus poetry is not Unlawful, and if it is not Unlawful when spoken, then it cannot be Unlawful if sung. The scriptural proof resides in a number of well-attested hadìth which al-Ghazālī cites. In one, 'A' ishah reports, "The companions of God's Messenger used to compete in reciting poems in his presence, and he smiled as they did so." ${ }^{15}$ She also reports the Messenger saying, "Out of poetry comes wisdom!" In fact alGhazāli is concerned to affirm the love of both religious and secular poetry that existed among the Prophet and his Companions. ' $\bar{A}$ 'ishah herself is reported as reciting the verse:

Those in whose shadow [my] life was lived have departed,

and I remain behind, like the skin shed by one sick with mange. ${ }^{16}$

Hadīth in the collections of both al-Bukhārī and Muslim include 'A' ishah's narrative: "When the Messenger arrived in Madinah, Abū Bakr and Bilāl fell ill, for there was an epidemic in the city. I said to Abū Bakr, 'Father, how are you feeling?' and to Bilāl, 'Bilāl, how are you feeling?' ${ }^{17}$ Thereafter, Abū Bakr whenever he had an attack of fever used to recite,

To every man waking in the morning amid his family,

death is closer than the strap of his sandal.

The Prophet's Abyssinian companion Bilāl after a fever had left him used to raise his voice and exclaim,

Ah, would that I knew whether ever again I would pass a night

in a valley with rush and panic grass about me, 
And whether one day I could again go down to the waters of Majanna, and (the folk of) Shāma and Tafīl once more show me their wells.

' $\bar{A}$ 'ishah continued, "I told this to the Messenger of God, and he replied, ' $\mathrm{O}$ God, make us love Madinah as we love Mecca, and even more so." 18 When alNābighah recited to him one of his poems, the Prophet said to him, "May God never let your mouth be closed." There is also a report transmitted by 'Amr b. al-Sharīd from his father who said, "I recited to the Messenger of God a hundred verses (qāfiyah) of the poetry of Umayyah b. Abī 'l-Șalt; at every one of them he exclaimed, 'More! More!' and finally said, 'In his poetry, he was almost a Muslim."19

We find in the authoritative Hadīth compilations of both al-Bukhārī and Muslim that the Messenger of God himself, as he helped the workers carrying bricks to build his mosque used to recite,

What we carry is not just fruit born from Khaybar

This burden is more righteous, Lord, more pure.

And on another occasion he recited,

O God, true life is that of the hereafter,

Be merciful then to both Anșār and Muhājirūn.

From the Companion Anas b. Mālik there is a report that the Prophet used to have him sing a cameleers' song sung for him when on a journey: Anjashah used to sing [to urge on the camels carrying] the women, and al-Barā'ah b. Mālik those carrying the men; the Messenger used to say to him, "Anjashah, go easy as you drive the camels carrying these fragile vessels!"

4) The fourth component is 'stirring the heart'. This provides the occasion for al-Ghazāli to present an argument not simply for the legitimacy of music, but to express a personal love for it, and an appreciation of its effects from personal experience. Its effect stems from the way in which it stirs the heart arousing an emotion that may dominate it. How this happens, how the rhythms that carry melodies connect with the soul in which it can produce wonderful effects, is a Divine secret. He stresses the variety of styles of music, and the different effects these can have on individuals:

Some sounds cause joy, others sorrow, and some lull to sleep; some cause laughter, others stir the emotions. Some cause movement of the limbs, of hand, foot and even the head in time with the rhythm. It should not be thought that this is caused necessarily by understanding the meaning of a poem. Rather it is a result of the sound of the strings of the instruments accompanying the singing of it. Indeed it is said that one not moved by the flowers of spring or the strings of the lute suffers from a malady for which there is no cure. 
How could it be due to understanding (the sense of the words sung) when the effect of hearing [samā $]^{20}$ something can be seen on an infant in its cradle. An agreeable sound stills its crying, and draws away its attention from whatever caused it to cry. The camel, although by nature a dumb animal, is stirred by the song of the cameleer. On hearing it, the beast finds heavy burdens light and from the energy derived from hearing it, finds long distances short. The energy stirred within it invigorates it, and makes it forget its weariness. You see camels under the burden of the litters and baggage they carry, when the desert tracks are long, and fatigue and weariness distress them, the moment they hear the song of the cameleer, they stretch out their necks and with ears erect listen to the singer and his song. Because of the energy (aroused by the singing), they quicken their pace until the litters and baggage on their backs bob up and down, and sometimes they drop dead as a result of the strain they endure as they move along, not realizing how heavy is the weight they are carrying.

Later this vivid picture of the power which music exercises on a camel is transfigured when al-Ghazālī draws a parallel between the task of the camel, to carry burdens, and the task of humankind to seek God, with the role of music in stimulating each. For the camel, in giving it access to energy, and for the human being, in arousing in him feelings of ecstasy of such power that it may even lead to the death of the person experiencing it. How music as this effect on the heart is a divine secret. He marvels at the variety of effects it can have.

Listening (to music and song) then has a perceptible effect on the inner-awareness [qalb 'heart']. Anyone not moved by it is deficient in some quality, lacks an evenly balanced disposition, and is far removed from spiritual insight. He is coarser and denser in nature than the camels and the birds, indeed than any of the beasts, for all of them are moved by melody and rhythm. This is why birds used to perch on David's head to listen to his voice (when he sang).

This variety and wonder in music extends to many areas of life and the divine secret of how it comes about is common to all living creatures. For humanity it offers a kind of consecration of life. Yet despite this wonderful power of music, and the wonder of participating in musical events, the authority of the Law is to be respected. Music is Permissible, and the legal status of listening to it differs according to circumstances, the instruments with which it is performed, and what is in the inner-mind (qalb) of the listener.

\section{Public Activities}

The variety in music, and the types of circumstances which might effect the legal status of the individual are shown in his account of seven public activities in which music has a recognised and socially accepted role and is regularly performed. 
These are: on setting out for the pilgrimage; on marching to war; in the heat of battle; on occasions of grief and sorrow; on occasions of celebration; to arouse and express 'romantic' love; and to reach out for union (wișa $l$ ) with the divine. The use of music in all these situations comes under the heading of legitimate sam $\bar{a}$. These activities are widespread, and their being long established is itself an indirect suasion that this use of music is Permissible. This is something alGhazālī celebrates and invokes their existence as an argument to extend this legitimate use of music. Nevertheless, at the same time he draws attention to incidental or attendant circumstances which under particular conditions may render the use of music inappropriate.

Yet he also cites certain caveats. As for the first: It is praiseworthy for intending pilgrims to march around their home towns beating drums, blowing on flutes and singing poems that describe the cultic sites to be visited, for this increases their yearning to perform this act of piety. In this case, the writing and use of poetry in other situations, for example by a preacher in the mosque for example, is permissible. By extension, it can also be argued that it is Permissible for poetry to be written for other purposes as well. He has a striking appreciation for the orchestral effect of the combination of the rhythms of rhyming prose sung by a beautiful voice to the accompaniment of flute and drum, and the impact this may have upon the heart. The Law however must be obeyed. The playing of certain wood and string instruments which are emblematic of evildoers is forbidden. Performance of this music must not be used to encourage those for whom it is Unlawful to undertake the Pilgrimage, or to encourage pilgrims to make the journey when the roads are unsafe, and there is danger of death.

This balance between delight in the use of music and poetry and concern for the individual's responsibility to the realities of legal obligation is shown in various ways in his discussion of the other occasions. In his discussion of the second situation he declares it right for commanders to use poetry to urge their men on to battle. He cites the lines of the famous poet al-Mutanabbī (d. 965):

Then if you do not die by the sword, as one honoured

You will die without honour and be a by-word for shame.

and

Cowards regard their cowardice as discretion,

such is the self-deceit of ignoble natures.

Yet for the individuals concerned, this is only Lawful if the war itself is praiseworthy (mamdüh), and in any case, the poems and the melodies to which they are sung must be different from those sung by intending pilgrims.

In his discussion of the 'Occasions of rejoicing' he shows vividly the value he puts on human happiness and celebration. He is concerned with the whole of life, 
secular as well as religious. His appeal to Revelation for this gives a central role to the Prophet. He gives an account of celebrations that took place on the arrival of the Prophet at Madinah at the time of his hijrah or migration from Mecca, and describes the women on roof-tops beating tambourines at the arrival of God's Messenger, while singing,

The full-moon is approaching us,

[He looms up] through the mountain passes of al-Wadā

We should give thanks for that to which a caller to God is calling ${ }^{21}$

This is praiseworthy, and other physical expressions of joy are also praiseworthy. It is reported of a group of the Companions that on this occasion they leapt for joy overcome by happiness. He takes this as a model to extend the occasions of this physical expression of rejoicing. Not only at the arrival of the Prophet, this is permissible at the arrival of any legitimate visitor, and in fact on any Permissible occasion of rejoicing. His emotional resonance with such celebrations is reflected in the hadith he invokes which describes the Prophet and 'A' 'ishah watching the Abyssinians playing their 'war games' in the courtyard of the Prophet's mosque in Madinah with the Prophet urging them on, "Keep at it, sons of Ardafa!"

These hadīth are all in the canonical collections of al-Bukhārī and Muslim. They are decisive proof-texts which establish that singing and amusement are not Unlawful, and they do so in various ways. The first concerns Amusement $\left(l a^{\prime} b\right)$, just as the fondness of Abyssinians for dances and amusements of various kinds is well known. Secondly, they were doing it in the mosque courtyard. Thirdly, the Prophet's encouraging words "Keep at it..." were an order to play the game with enthusiasm - so how can it be thought that such amusements are Unlawful? The fourth is the Prophet's response to Abū Bakr and 'Umar who objected to the amusement and wanted to stop them; the Prophet pointed out that it was a feast day, a time of celebration, and these games were ways of celebration. The fifth is the length of time (the Messenger) spent watching and listening to them, because he approved of the happiness ' $\overline{\mathrm{A}}$ 'ishah found in them. Particularly moving are the Hadīths he cites relating to ' $\bar{A}$ 'ishah, Hadīths which illustrate not only the legitimacy of pure entertainment but of the humanity and tenderness of the Prophet. This confirms that a solicitude for the happiness of women and children which allows them to watch such games is preferable to an ascetic harshness and self-mortification that condemns and forbids this. These arguments and citations establish that singing, dancing, beating the tambourine, games displaying leather shields and lances, watching the dances of Abyssinians on occasions of celebration, these are all Permissible. This notion of 'festival day' also includes weddings, banquets, the naming and cutting the hair of an infant, circumcision, return from a journey, and every other reason for celebration, that 
is to say everything at which celebrations are legally permissible. Celebration is permissible as well at visiting, meeting and gathering with one's brethren for dining or conversation.

The final two occasions treat human and divine love respectively. The former might be understood as endorsing the use of music to celebrate 'romantic' love. If a song is performed in the presence of a wife or concubine, it enhances the love that exists between them. When the two are apart song sweetens the pain of longing for an absent beloved-Ghazālī, no less than Shakespeare, knew that 'parting is such sweet sorrow'. This is among the kinds of pleasure and enjoyment Permissible in this world, as the Qur'ān states (al- 'Ankabüt 29:64): And what is life in this world but amusement (lahw) and play (la ib), and song is part of this. Even so, there is the warning that if the singer create in the hearer's mind the image of a person not lawful for him to look on, and he be overcome by feelings of illicit love, such samā' is unlawful for him. This is not because of anything intrinsic to the $s a m \bar{a}$, but because of the passion it has awakened in a vulnerable person.

The seventh public activity is the $s a m \bar{a}$ ' session attended by: "one who loves God ardently and who yearns to meet Him, for he looks upon nothing without seeing Him within it - glorious is He beyond compare - while no sound reaches his ear without his hearing Him by means of that sound or within it. In this is a clear echo of the words of the invocation or remembrance. For such a person sam $\bar{a}$ ' rouses his yearning, confirms his love and passion and sets fire to his heart producing in it 'states' $(a h w \bar{a} l)$ flowing from divine disclosures and graces which are indescribable. One who has tasted them knows them; one whose perception is too weak to taste them, denies them."

In the technical language of Sufis these interior states $(a h w \bar{a} l)$ are termed wajd 'ecstasy', a word derived from the root wajada 'to find' and which conveys the connotation of mușādafah 'to light upon unexpectedly' - since the Sufi discovers interior states not experienced before this act of Listening ( $\operatorname{sam} \bar{a})$ ). These inner experiencings set the heart ablaze with their fire, and cleanse it from impurities just as fire refines what is melted within it. From such purity of heart may come visions or 'unveiling' deemed the highest quest of those who love God, and the ultimate fruit of every work of devotion. It is good works that lead to these favours, not acts of disobedience, or even merely Permissible acts.

Ghazālī exclaims: "Glorious beyond compare is He who is veiled from being visible by the very intensity of His manifestation, and is hidden from sight by the radiance of His light. Were it not for His being hidden by seventy veils of His light, the glories of His countenance would consume the sight of all who beheld Him due to the beauty of His presence. Were it not that His manifestness is the cause of His being hidden, human minds would be overwhelmed, hearts 
filled with confusion, their physical strength abandon them, and their limbs be in disarray." It is with this in mind that in the " $f a t w \vec{a}$ ' given at the conclusion of chapter two, he states that for those chosen, participation in $s a m \bar{a}$ ' is legally to be considered mustahabb: an activity rewarded even if its omission is not punished. His treatment of these seven occasions of public activity is brought to a moving conclusion by a striking reference to the Christian Gospel: There was someone who said, "I saw written in the Injül,

'We have sung for you, and you have not been filled with delight, we have played pipes for you, and you have not danced'

[i.e. We have sought to fill you with longing by telling of God,

but you have not longed for Him].22

\section{Five Impediments}

He now presents five obstacles or impediments to the permissibility of listening to music on public occasions which may make participation in them Unlawful. A sam $\bar{a}^{\prime}$ session consists of the singers, the instruments accompanying them (including the musicians), and the spiritual auditors. These impediments may relate to (1) the vocal performer, (2) the musical instruments played, (3) the words of the songs sung, (4) the age and disposition of the auditors and finally (5) their levels of intellectual and spiritual understanding. In al-Ghazālī's discussion of these impediments, among his concerns, along with his explicit juridical commitment, is to narrow the area in which these impediments may have effect. This is the obverse of his previous discussion of seven accepted public occasions on which music is performed, where he showed a concern to broaden them.

(1) Regarding the first, the vocal performer, he sees the possibility of an impediment if the performer is a woman outside the prescribed range of relationships, and therefore one whom it is not lawful for participants to look on and listen to. His opinion is that whether this constitutes an impediment or not depends on whether there is fear it may incite temptation, reiterating that this is crucial to its being taken as an impediment. He emphasises that a woman's voice in conversation is not deemed a temptation, otherwise it would be forbidden to speak with her, or even listen to her voice. He insists that a woman's voice is not part of her pudenda ('awrah 'privy parts', as defined in Islamic Law) when not singing. In the time of the Companions women constantly spoke with men, exchanging greetings with them, asking opinions, putting questions to them, entering into discussions and so on. He concludes, "The answer to the question as to whether it is Permissible to listen to a woman singing differs according to the circumstances of the woman and the man in question, as [for example] whether the man is young or old." ${ }^{23}$ 
Ghazālī now clarifies, "It is not unusual for a legal ruling to differ according to circumstances. Thus it is our view that an old man may embrace his wife while fasting, but a young man may not. This is because the embrace may lead him to have sexual intercourse with her during the fast, and this is proscribed. Listening to her may result in a temptation to look at, and approach her, and so be declared Unlawful, but this too may vary according to the circumstances of the individual concerned." His concern with circumstances, and their bearing on the legal status of an individual's act as opposed to that of the act itself, is characteristic of alGhazālī's legal thinking.

(2) The second impediment is present if the instruments played are emblematic of, or closely associated with, alcohol drinkers or transvestite musicians namely specific types of flutes, stringed instruments and drums. But this apart, the principle that 'what is not forbidden is permitted' applies.

(3) A third impediment exists if the words recited or sung include any obscenity, or any untruth concerning God, His Messenger, or the Companions. However, such objectionable lyrics need not exclude the formal 'sensual prelude' (nasīb) of the classical love ode (qașìdah) which often included a very stylised description of a woman's cheeks and hair locks, or the beauty of her figure and deportment. The imagery so presented is highly allegorical and the singing of such a poem is not Unlawful. Nevertheless, a listener may not apply the features of this allegorical figure to any particular woman other than one with whom he may have lawful sexual relations. If a participant is prone to this weakness, he should avoid sama' ' altogether, for it could lead to sin.

Nevertheless, words may have many meanings, being used metaphorically and understandable in various ways. Everything could be understood as a sign of God - even the sensual prelude may communicate a spiritual meaning for one whose heart is overwhelmed by love of God. He will reflect on the blackness of a lock of her hair and see it as a metaphor for the darkness of unbelief; or the healthy bloom of her cheek as indicating the light of faith. At the mention of communion (wișa $l$ ) the auditor may think of the meeting with God, while separation (firāq) may bring to mind the barrier ( $h i j \bar{a} b$ ) between him and God befalling those who are rejected. This being so, one overwhelmed by an ardent love of created things should be wary of $s a m \bar{a}^{\prime}$ sessions no matter what the words are. But if one is overwhelmed by ardent love of God, the words of a poem or song cannot harm him, nor hold back his understanding of the subtleties of meaning which indicate Him and assist his sublime quest.

(4) The fourth impediment resides within the self of the listener. Ghazāli recognises that participating in musical performances results in a heightened emotional state. For the young or immature novice this excitation may be unsettling and render the listener susceptible to be overcome by passion or inappropriate 
excitement. When auditing a poetic sensual prelude, such a novice is unable to hear the stylised description of the allegorical beloved without identifying her with an individual woman whom he knows and passionately desiring her, then participation is forbidden him. In his case, sam $\bar{a}$ ' becomes an ally of Satan and an enemy of reason, and is Unlawful for him.

(5) The fifth impediment resides in the class of common people termed the 'awāmm, those who have no high spiritual, intellectual and perhaps social aspirations, for whom listening to a musical performance is simply a form of entertainment and diversions. His comment is succinct and nuanced: If participating in $s a m \bar{a}^{\prime}$ does not lead to sin, it is Permissible, just as is any other pleasure. However, the proper course is moderation; an obsession with sam $\bar{a}$ ' just as with anything else, is sinful. "Something beautiful may become ugly because of excess. Even bread in excess may be unlawful. Thus if participation in samā becomes habitual and even an obsession, to the point that even when he spends most of his time at it, he is still not satisfied, then he is to be treated as one legally incompetent and his testimony not accepted, because over-indulgence in amusement is a crime." Just as a minor sin committed over a long period may become a major one, so an act in itself Permissible may over time become a minor sin. It would be like following the footsteps of the Sudanese and Abyssinians and spending hours watching their games. Such over-indulgence is forbidden, even though in principle the act itself, watching, is not forbidden, for the Prophet himself did it. The same applies to playing chess. It is Permissible, but over indulgence in it is highly Undesirable.

\section{Rebuts Objections}

Ghazāli faces directly the objection: 'Since you concede that participation in sam $\bar{a}^{\prime}$ sessions is Permissible in some circumstances and not others, why do you begin your discussion with the apodictic statement that it is Permissible? A categorical answer of this kind to such a complex matter may be misleading'. He replies by denying the validity of the question: a categorical statement is only to be excluded when the distinction made is with the subject being considered; however, if it is made as a result of incidental circumstances attending it, there can be no objection to such a statement. This lies at the heart of his moral theology. Ghazāli insists that he is right to make an apodictic statement, and that all the distinctions he makes are the result of incidental circumstances. He gives three examples. Honey is Lawful, but for one of 'sanguine' temperament who may be harmed by it, it is Unlawful. Wine is Unlawful, but for someone who is choking, when no other liquid is available, to drink it is Permissible. Trading is Lawful, but when the call to prayer supervenes, to continue trading is Unlawful. 
The incidental circumstances affect the status of the act as performed by the individual, while not changing the status of the activity in itself.

He sums up his position: $\operatorname{sam} \bar{a}^{\prime}$ sessions are among those things which are Permissible from the legal standpoint that they are an activity involving listening to a pleasing sound with rhythm and having meaning while stirring the heart. They may be regarded as Unlawful due to various incidental circumstances but not on the grounds of anything within the activity itself. ${ }^{24} \mathrm{He}$ then rests his case with the assertion: "Since we have removed the veil obscuring evidence that $\operatorname{sam}_{\bar{a}}$ ' sessions are Permissible, we may disregard the view of anyone who having been shown this evidence, still disagrees with us," and thereby brings to a close part two of this first chapter. ${ }^{25}$

In part three of chapter one al-Ghazâli responds to a number of proof texts used by well-known authorities of the first three Islamic centuries to argue that participating in $s a m \bar{a} \bar{a}^{\prime}$ sessions is Unlawful. These proof texts include Qur'ānic verses, Prophetic Hadīth, and narrations from Companions and Followers. His method is either to offer a context for the particular statement or narration which precisely defines the area which it applies; or to question the way it has been understood and thus the validity of conclusions drawn from it by the earlier authorities. He does this by applying the principles he expounded earlier in this chapter.

Three examples may suffice. One is based on sürah Luqmān 31:6, And of humankind are those who purchase the amusement of story-telling (lahw alhadìth) to mislead others from the path of God. Ghazālī refers to statements by the Companion Ibn Mas' ūd and the Followers al-Ḥasan al-Bașrī and Ibrāhīm al-Nakha ' $\overline{1}$ who all interpreted lahw al-hadīth as 'singing' and who associated this verse with a report from 'A' ishah, "The Prophet said, 'God has declared (everything to do with) a singing girl is Unlawful: selling her, the price paid for her, and instructing her'." Ghazālī replies that here, by a singing girl is specifically meant a slave girl who sings for men at a drinking session. The singing of such a woman for evildoers and those whom it may lead into temptation is Unlawful. But it is incomprehensible that on the authority of this tradition, the singing of a servant girl to her owner - and the listening to her by someone other than her owner when no temptation is likely to arise - be Unlawful. This is proven by narrations concerning two servant girls singing in 'A 'ishah's house. To which he adds, any purchase of amusement to lead people astray from the path of God is Unlawful; but not all singing is for this purpose! Were the Qur'ān itself to be recited in order to lead people astray from the path of God, even this would be Unlawful. ${ }^{26}$

The second is a report that Nāfi ${ }^{27}$ once said, "I was walking along a path with Ibn 'Umar when he heard a shepherd playing his flute. Ibn 'Umar put his fingers 
in his ears and left the path, asking time and again, 'Nāfi ', can you still hear it?' until I said, No! He then took his fingers [from his ears], and said, 'I saw the Messenger of God do this'." To this al-Ghazālī responds: There are many ways of interpreting anecdotes such as this; as for Ibn 'Umar's putting his fingers in his ears, what argues against his regarding listening to the sound of the flute as Unlawful, is that he did not order Nāfi' to do the same (i.e. also to put his fingers in his ears), and he raised no objection to him listening to it. Ibn 'Umar did so only because he felt that, in the situation he was in then he should keep his hearing and his heart unhindered by a sound that might attract it to amusement, and distract him from a thought or a reflection (dhikr) within his heart which was more important. The fact that the Messenger of God did the same - given that Ibn 'Umar did not forbid it - does not indicate that he regarded it as Unlawful, only that it was preferable for him [in those circumstances] not to listen to it.

The third example is the argument early authorities based on a statement attributed to the Companion 'Uthmān, "I have not sung, I have not indulged in sexual fantasies, nor have I ever touched my penis with my right hand since I used it to pledge allegiance to the Messenger of God." Ghazāli replies: "Let it be granted that indulging in sexual fantasies and touching the penis with the right hand are Unlawful. Yet if this statement is adduced as proof that singing also is Unlawful, then how can it be proven that 'Uthmān avoided only acts that are Unlawful?" In the first two examples it is the contextual background which is significant. However, the third instance illustrates in an unexpected way the basic dictum that 'everything not Unlawful is permitted'. The rhetorical question "How can it be proven that 'Uthmān avoided only acts that are Unlawful?" is far reaching in its implications. It does away with the 'legal creep' of a certain type of mind which seeks to find grounds to exclude change, avoid development and the unfamiliar, and has an excessive concern or even a phobia about reprehensible innovation (bid'ah). ${ }^{28}$

\section{Respecting Human Dignity}

Alongside the heights of spiritual experience, Ghazālī has a down to earth awareness of daily life and the common issues of living. It is his adherence to this principle and an innate sense of courtesy and respect for human beings which leads him to respect and find space for social customs which may be unfamiliar. As on other occasions, an example is found in his development of a comment on a detail of ritual practice. Thus if during a sama $\bar{a}$ ' performance an individual is overcome by ecstasy and stands, the other participants should stand with him as a sign of communal solidarity. Similarly if one participant removes his turban or it falls off, his fellows should also remove their turbans. 
This courtesy has wider applications in social life. Just as individuals should respect each other in $\operatorname{sam}_{\bar{a}}$ ' sessions as a community exercise, so they should respect differing social customs in different countries. Every people has its own customs and should be accepted as they are, especially in matters involving good fellowship, courtesy, and the comfort of mutual support. "Every people has its style of life (rasm), and people must be treated according to the way they are", as is stated in this report (khabar), especially when there is in it good association, courtesy, and healing of the heart by mutual help. "It was not the custom of the Arabs to stand when a visitor entered their presence. Indeed, in some circumstances the Companions used not to stand for the entry of the Messenger of God. But since there is no general prohibition of it we see no harm in it in countries in which it is the custom to honour a visitor by standing, for by it, it is intended to respect and honour the visitor, and set his heart at ease." To those who object that this may be a reprehensible bid 'ah and was not the practice of the Companions', he tartly replies, "Not everything with the legal status of Permissible has been transmitted from the Companions." True, one should exercise caution in adopting an innovation at variance with properly transmitted practice, but this does not in itself justify the prohibition of anything.

Such sensitivity to the human condition is shown above all in al-Ghazālī's role as a spiritual director. He is aware of highs and lows experienced in spiritual life, and innate differences between levels of spiritual attainment. He understands how a person even of great devotion may encounter aridity when reciting the Qur'ān because of over-familiarity, yet may experience an emotional response to poetry - and feel guilty because of this. Not all devotees gain a spiritual experience from the Qur'ān at its every reading. Some find at times they can be moved to ecstasy by the songs of bards ( $q a w w \bar{a} l)$ and not by the Qur'ān. Ghazāli recounts the tale of Abū 'l-Hasan al-Darrāj (d. 932) who came to Baghdad to visit the renowned Shaykh Yūsuf. When he reached Baghdad and asked for the Shaykh everyone answered, "why do you want to see that unbeliever?" Nevertheless Abū 'l-Hasan continued to search and finally found him - a handsome old man with a fine beard - seated in the prayer-niche mihrāb of a mosque reciting from the Qur'ān. When the Shaykh saw Abū 'l-Hasan he asked him to recite verses of poetry to him. Abū 'l-Hasan recited two couplets. The first tells of a broken (human) relationship, and the second reflects upon it at a deeper level,

It is as though when I was with you,

"would that" was always on your lips,

[should we not have said:] Would that we had lived at a time, when there was no need to say "would that".

At these verses Shaykh Yūsuf closed his Qur'ān and wept copiously. Then 
he stated, "This is why people say I am an unbeliever; I have been reciting the Qur'ān since the dawn prayer this morning (thus for over three hours) and not one tear has fallen from my eyes, yet at your reciting these two lines, it is as though Judgement Day was being enacted in my heart."

Ghazāli understands the man's pain and his dilemma, and offers comfort. "Even when hearts are ablaze with the love of God, an unfamiliar line of poetry may move them in a way that reciting the Qur'ān does not. It is due to the rhythm of the poem, and the way its meaning matches the mood current in a listener's heart." He explains further that the Qur'ān is known by heart by very many people. When first heard its effect on the heart is very great; on a second hearing it is weaker; and upon a third it may be almost non-existent. He sums up this issue: A Qur'ān reciter cannot recite an unknown portion of Qur'ān for every time and occasion, for the Qur'ān is closed and nothing can be added to it. Poetry and music then may have an important if not central role in one's spiritual life, and may complement revelation in one's quest for the spiritual experience of ecstasy. This is the case even when the seeker may not discover in the Qur'ān itself the desired emotional response.

Ghazālī offers abundant examples of emotionally charged ecstatic responses to auditing verses from the Qur'ān, whose words are of such power that 'Were We to reveal this Qur'an to a mountain, you would see it bow in homage, then shatter out of fear of God' (al-Hashr 59:21). The Prophet himself wept when he recited, or had recited to him 'Even if you punish them, they are still your servants' (alMà'idah 5:18). The Prophet upon hearing a verse telling of God's mercy, 'When they listen to what has been revealed to the prophet you see their eyes overflow with tears because of what they recognise as the truth (al-Mä'idah 5:83), he shouted aloud for joy. At a more sophisticated level, al-Ghazālī continues, the Qur'ān is a remedy for humankind in all its states $(a h w \bar{a} l)$. But it may happen that something in a particular recitation of the Qur'ān may not concur with the state of a specific individual at a definite time, which may expose him to the danger of feeling an aversion to the Word of God. Only what is appropriate to the current state of the heart can stir it. If a person is dominated for example by sorrow or yearning, how can the Divine words (al-Nisā' 4:12) 'Allāh makes a testatory ruling in regard to your children' resonate within it? For a very few devout persons, the divine name Allahh itself may be enough to fill the mind. Others may reflect that God cares for his creatures, and so think, 'Since He cares for our children after our death, we do not doubt that He cares for us' (al-Baqarah 2:26). For many others, those whose thinking cannot extend this far - and recognising that the Qur'ān cannot be adapted to one's personal mood or inner condition $(h \bar{a} l)$, whereas poetry can - it is necessary to turn to song. Indeed, some shaykhs have recourse to songs in sam $\bar{a}{ }^{\prime}$ sessions rather than reciting passages from the Qur'ān. ${ }^{29}$ 
The result of these considerations is that poetry - which along with certain amusements al-Ghazālī has already established is Permissible - may provide spiritual benefit. Against this, some had invoked the hadith from the Companion 'Uqbah b. 'Āmir who narrated that God's Messenger said, "Every form of amusement that a man indulges is pointless (bātil) apart from training a horse, archery, and foreplay with a wife." 30 Ghazālī's reply is that the use of the term $b \bar{a} t i l$ does not establish that what was referred to is Unlawful; it merely indicates that there is no merit to be gained from it. Watching the Abyssinians indulge in war games (and what could be more pointless! Ghazâlī exclaims) falls outside the three items exempted from being worthless; however this cannot be regarded as Unlawful on the basis of this authority, since the Prophet himself watched them eagerly, and they gave pleasure to him and his wife ' $\bar{A}$ 'ishah. The significance of this can be extended by analogy. In foreplay with one's wife, there is nothing to be gained other than pleasure. It therefore follows that taking pleasure in gardens, listening to bird's voices, and various diversions by which humans amuse themselves can in no way be called Unlawful, even though they might be described as pointless. ${ }^{31}$

Ghazāli does not to leave the matter at that. Amusement, whether judged worthless or not, has a positive role to play in human life. It refreshes the mind and relieves the stress of study, and may be enjoyed for this purpose as something good. This is the case with $s a m \bar{a}^{\prime}$ sessions even for the person for whom they are merely a source of pleasure and recreation. The mind is soothed, and its proper priorities are re-established, enabling one to give due attention to necessary worldly matters such as earning a living or practicing a trade, and to religious practice including performing prayers and recitation of the Qur'ān. Thus a scholar should then take a break from his studies on Friday since a day's diversion will replenish his energy for the rest of the week. Recreation is an aid to work, and amusement helps concentration. Only the Prophets have the strength to endure total concentration and the uninterrupted rigour of Truth. Yet amusement should not become habitual nor be taken to excess, while even a person who fills his time with supererogatory prayers should from time to time take a break from them, since excessive prayer might be undesirable (makrūh).

\section{Conclusion}

Islam was never a religion of orthopraxy alone. Even without esoteric interpretations of the Qur'ān developed by early Sunnī mystics or the Shī'ah, a profoundly inspiring spirituality is evident in a literal reading of the Qur'ān, complemented in Hadīth and the hadìth qudsì. The achievement of al-Ghazālì is in demonstrating how the Law, legal observance, spirituality and mysticism are 
integral parts of a seamless whole. He exemplifies the importance in Islam of a Humanist tradition which values all secular activities within the Law, seeing in them the potential for advancing spiritual life by means of worldly things. He might equally be reputed for celebrating the grasp of the human mind, and the delights in creation proper to each of the five senses.

At a primary level his work on spiritual audition exemplifies the treatment of a juridical question which receives a juridical answer. More than this, it offers an example of insight, spirituality, and dialectic mingled with human awareness, and studying it opens the door to spiritual experience. This work presents a view of humanity existing at a diverse range of spiritual levels, of the wonder of divine love, of the humanity of the Prophet, and of the legitimacy of human joys and pleasures - foremost being poetry, music and dance. In his argumentation al-Ghazālī displays his love for these activities and disengages them from unnecessary legal restrictions by seeing them as a legitimate concomitant of the Islamic revelation. Ghazāli thereby lays the foundation for the development of a God-centred Humanism which gives due and full respect to the Law. Part of the wonder of his work is that while addressing a specific issue, it offers an informed and informing dialogue between the particular and the general. The legal status of $s a m \bar{a}$ ' provided the author with an occasion to reflect on the richness and diversity of religious life and experience within Islam, the circumstantial factors that have to do with the framing of specific provisions of the Law, and the status of the individual in complying with it.

His thinking offers us a model for existing in the contemporary world. Along with his active concern for holding fast to the Law, and his care for individuals of every spiritual level, he sees no need to be limited by the practice of the righteous ancestors: "Not everything with the legal status of Permissible has been transmitted from the Companions." We may extract several essential principles valid for Muslim thinkers and planners in their search for refreshing the basis of their legacy.

- By carefully distinguishing between legal provision and attendant circumstances, there emerges the possibility for creative development which avoids innovation.

- Ghazālī maintains the sanctity and authority of the Law, but frees Muslims from imposition of unnecessary legal constraints. Awareness of this freedom should be strengthened and heeded.

- Ghazālī demonstrates the space in Islam for a Humanist tradition, one which values all secular human activities within the Law and sees in them the potential for advancing spiritual life. This forms an essential basis for reviving Islam's reason for being. 


\section{Notes}

* Anthony H. Johns, Emeritus Professor at the Australian National University in Canberra, held a chair in the Faculty of Asian Studies from 1963-1993, and is a renowned specialist in Sufism in the Malay world, Islamic History and Institutions, and the foundation texts of Islam. In the course of his distinguished career in Toronto, Jerusalem, Oxford, Tokyo, Cairo and Indonesia he has published significantly on Qur'an and Qur'anic exegesis, and he now serves as a member of the editorial board for Journal of Qur'anic Studies. Among his recent works is Islam in World Politics, ed. Nelly Lahoud and A.H. Johns (Routledge, 2005). Currently he is Visiting Fellow in the Division of Pacific and Asian History, of the Research School of Asian and Pacific Studies, at the Australian National University.



2. Kitāb ādāb al-samā' wa l-wajd, book X of his major opus Ihyā' 'Ulūm al-Dīn (Beirut: Dār alMa rifah li-1-țibā'ah wa 1-nashr, n.d.) pp. 268-306.

3. [For orientation on Sufi techniques of $\operatorname{sam}_{\bar{a}}$ ' 'spiritual-audition', see overview by Jean During and R. Sellheim, "Samā"', Encyclopedia of Islam, $2^{\text {nd }}$ Edition, ed. P. Bearman et. al.; and Kenneth S. Avery, A Psychology of Early Sufi semā': Listening and Altered States (Abingdon \& New York: RoutledgeCurzon, 2004). -Editor]

4. [The technical Sufi term wajd often rendered 'ecstasy', derives from verb wajada ('to meet with, come face-to-face with, directly confront'), and indicates intensified inner experiencing of one's personal reality arising from sincere self-observation marked by a temporary condition of heightened self-awareness. Such episodes of self-confrontation (wijdān) may be whelmingly blissful, or unbearably distressing and overflowing with pathos - thus 'inner-catharsis' is the true import. Sufi exponents generally cautioned against over-reliance upon and unchecked attachment to such temporary episodes, viewed as galvanising moments towards real self-knowledge. -Editor]

5. Idfa' al-ḥudūd 'an al-muslimīna mā wajadtum, fa-in wajadtum li-l-muslimīna makhrajan fa-khallū sabīlahu.

6. Ihyä', p. 284.

7. [On the legal controversy over its permissibility, consult Arthur Gribetz, "The Samā' Controversy: Sufi vs. Legalist", Studia Islamica 74 (1991) pp. 43-62. -Editor]

8. Of our renderings of these terms, perhaps makrūh requires comment. It is often translated literally as 'hated' or 'disliked'. These are inadequate to distinguish it from harām, since in practice there is a fair amount of flexibility available when this legal ruling is given. 'Undesirable' retains this flexibility, while not giving a free pass to performance of the designated activity.

9. Ihyā', p. 306.

10. Ihyā', p. 269.

11. Ibid., pp. 269-270.

12. Al-Tirmidhī cites this tradition in his work on the beautiful qualities of the Prophet entitled Shamā' $i l$ $a l-N a b \bar{l}$, on the authority of the Basran Successor Qatādah, who then added his own words: "Your prophet was handsome of countenance, beautiful of voice...."

13. From al-Tirmidh̄̄'s Sunan, cited in the introduction (taqdimah) to Kitāb tilāwat al-Qur'ān.

14. Ihyā', p. 271.

15. Tirmidhī, Sunan.

16. D. B. Macdonald, in his study on al-Ghazālī's treatise on music in JRAS (19xx) p. 215, identified this couplet as belonging to the pre-Islamic bard Labīd b. Rabī'ah.

17. Bukhārī and Muslim; related by al-Bukhārī on the authority of the Companion Ubay b. Ka 'b.

18. Ihyä', p. 273.

19. [Umayyah b. Abī l-Șalt (d. $9 \mathrm{H} \backslash 630)$ was a contemporary of the Prophet Muhammad and seeker of monotheist truth (al-hanafiyah) whose poetry echoed certain ideas of Islam. He claimed to receive inspiration through two white birds who spoke into his left ear; see Ibn Hajar, al-Ișābah (Cairo, 1328) I, pp. 129-30. -Editor]

20. Note that al-Ghazālī is gradually moving from "listening sama $\bar{a}^{`}$ " in general to the specific sense of sessions of $\operatorname{sam}_{\bar{a}}^{\prime}$ (spiritual audition).

21. Cited by Hāfiz al-Bayhaqī in Dalā'il al-Nubuwwah; also related by al-Bukhārī and Muslim on the 
authority of Umm 'Ațiyah without the mention of duff and alhān; see Ihyā', p. 277.

22. Compare the New Testament, Matthew 11:17; Luke 7:32.

23. Ihy $\bar{a}^{\prime}$, p. 282.

24. Ihyä, p. 283.

25. Ihyä', p. 284.

26. Ihyā', pp. $284,285$.

27. Abū 'AbdAllāh Nāfi' of Madinah (d. 114 H), the mawlā 'client' of Ibn 'Umar.

28. Ihyā', p. 285.

29. Ihyä, , p. 285.

30. Ihyā', p. 285, n. 3. This hadīth is cited by the four așhāb al-sunan, yet exhibits certain inconsistency.

31. Ihyā', p. 286. 